\title{
The North Atlantic trade with Iceland, Shetland, Orkney and the Faroes and the policy of the Hanseatic Diet (1369-1535)
}

\author{
ROLF HAMMEL-KIESOW
}

Hammel-Kiesow, R. 2019. The North Atlantic trade with Iceland, Shetland, Orkney and the Faroes and the policy of the Hanseatic Diet (1369-1535). AmS-Skrifter 27, 27-42, Stavanger. ISSN 0800-0816, ISBN 978-82-7760-183-0.

This paper explores the limits of the Hanseatic Diet's ability to regulate Hanseatic trade with Iceland and the North Atlantic island groups of Shetland, Orkney and the Faroes*. It comes to the conclusion that the Hanseatic Diets prohibited direct commercial links to Shetland, Orkney and the Faroes consistently from 1416, but turned a blind eye to the Iceland trade. The reasons for this inconsistent policy were the necessity of maintaining the Bergen's monopoly on the stockfish trade (which was also in the interest of the Danish-Norwegian crown), while at the same time keeping the door open for Hanseatic merchants who were not active in the Bergen trade to forge commercial links with Iceland, albeit at their own risk. The representatives of the Hanseatic towns often preferred to leave an issue undecided, in order to keep as many options open as possible. The huge divergence in the interests of merchants and towns forced the Diet to dissemble, pursuing policies out of the public gaze which subverted the resolutions the Diet had passed for public consumption.

Rolf Hammel-Kiesow, Europäisches Hansemuseum Lübeck, An der Untertrave 1, D-23552 LÜBECK, GERMANY.

E-mail: mail@hammel-kiesow.de

Keywords: North Atlantic trade, stockfish, Hanseatic towns, merchants, Hanseatic Diet, two-faced policy, monopoly, Bergen

Gathering intermittently for their Diets in the second half of the fifteenth century, the representatives of the Hanseatic towns repeatedly discussed trade with the North Atlantic islands of Iceland, the Faroes, Shetland and Orkney. ${ }^{1}$ Hanseatic merchants and skippers may have been visiting these islands for a hundred years or more, in order to buy dried fish, a fact which just occasionally attracted the Diet's attention, ${ }^{2}$ since these voyages violated the prohibitions of the Norwegian crown. ${ }^{3}$ The prohibitions had been issued repeatedly since the end of the thirteenth century because they breached the monopoly of the town of Bergen on North Atlantic dried fish and other goods, about which more anon. However, these voyages only became the subject of continuing debate from the 1480s.

The goal of this paper is to give a blow-by-blow account of the deliberations of the Hanseatic Diet on the subject of the North Atlantic trade and of its attempts to achieve a consensus on the matter, all the while taking into account the divergent interests of the parties involved. Did the Diet in fact prohibit trade with Iceland and/or the other North Atlantic islands? If so: when?, for what period? and in whose interest? However, these questions have to be posed against the background of the revolutionary conception of the Hanse and the legislative powers of its Diet which recent scholarship, in particular the seminal work of Ernst Pitz, Bürgereinung und Städteeinung has put forward. ${ }^{4}$

We will treat briefly the impact that the North Atlantic trade of Hanseatic merchants had on both the royal and the Hanseatic staple in Bergen, followed by the state of research on our topic and by a condensed overview on the North Atlantic trade before 1450. The body of the article introduces, firstly, the parties interested in the North Atlantic trade, then deals, secondly, with the deliberations on this subject in the Diets from the second half of the fifteenth century to the 1520 s when the discussions on this topic found a conclusion. Thirdly, we summarize the policies of the delegates 
to the Diet and, fourthly, try to answer the question what the consequences of the diverging interests of the different parties were. Finally, a conclusion in seven points closes the paper.

\section{The impact of North Atlantic trade on Bergen}

Direct contacts between Hanseatic merchants and Iceland and the North Atlantic island groups had deleterious effects on the income of the Norwegian crown from the Bergen staple and on the income of the Hanseatic Kontor there. Hitherto Bergen had been the emporium par excellence for the North Atlantic fish trade. Indeed, prohibiting alien merchants from frequenting the regions north of Bergen and the tributary islands (Greenland, Iceland, the Faroes, Shetland and Orkney) had made Bergen the central staple. Both the king of Norway and the Hanseatic Diet had a vital interest in upholding Bergen's staple function. For the crown, the Bergen staple had the advantage that imports were customed and sold in town and that the king could exercise his right of purveyance there. ${ }^{5}$ For the Norwegian nobility, for the rural population and the inhabitants of Bergen alike, the staple had the advantage of reliably providing imported merchandise for purchase. The desire to corner the market for Norwegian merchants and fishermen, ensuring them of a monopoly on the considerable trade between Bergen, the northern Norwegian coast and the tributary islands, surely also played a significant role, not least because the crown derived considerable income from it. ${ }^{6}$ One member of the Norwegian Council of the Realm compared the Bergen staple in 1425 with the English wool staple in Calais (stapula de stokfisk sicut Calisie de lana), ${ }^{7}$ underscoring its immense economic importance for the country.

Turning to the other side of the Bergen trade, Hanseatic merchants were able to dominate the stockfish trade in Bergen in the fourteenth century due to the huge amounts of grain which they could offer for sale. ${ }^{8}$ This ensured them not only control of the trade between Bergen and the Hanseatic heartland, but also of traffic between Bergen and England, from which they managed to eject their Norwegian and English competitors almost completely. Consequently, the Hanseatic merchants profited from the Bergen staple, since all fish from Iceland, ${ }^{9}$ the North Atlantic islands and northern Norway had to be delivered to Bergen for sale. It was through Bergen that all imports and exports connected with the stockfish trade were funnelled, and the trade was supervised so exactingly that hardly any Hanseatic merchant dared to violate the Hanse's privileges and endanger the Hanse's paramount position. Bergen was, therefore, not only a royal Norwegian staple, it was a Hanseatic staple as well.

\section{The state of research}

Scholarly opinion is far removed from consensus. In particular, scholars have not worked out the policies of the Hanse on the North Atlantic trade in detail, principally because they have studied trade with Iceland on the one hand and trade with Shetland on the other hand separately, with the Faroes and Orkney being mentioned, at best, in passing. Consequently, they focussed narrowly on those policies of the Hanseatic Diet which affected one - and only one - of the Hanse's North Atlantic trading partners. An unfortunate side effect of this tendency towards tunnel vision was researchers' tendency to deliver sweeping statements which, upon closer examination, proved to be scholarly fantasies, not supported in the least by the sources.

In 1889, Ernst Baasch wrote that 'the Diet repeatedly prohibited direct trade with Iceland', without, however, feeling obliged to provide any proof whatsoever. ${ }^{10}$ In 1900, Friedrich Bruns asserted that the Wendish towns forbade Hamburg from trading with Iceland in 1482, effective from the following year. ${ }^{11} \mathrm{~A}$ second interdiction of the Iceland trade was, so he stated, promulgated in $1521 .{ }^{12}$ In regard to the North Atlantic trade, Klaus Friedland wrote in 1973 that 'it is hopeless to attempt to build up a clear picture from the statutes and ordinances of the Diet and the Danish crown'. It is difficult to understand, he continued, 'why the Hanse prohibited trade with the Shetlands, Orkneys and Faroes so early in its history and why it held to this policy so doggedly, while it did not bother to flank the Danish prohibition of the Iceland trade with decrees of its own until comparatively late and then instantly forgot about the matter altogether. ${ }^{\prime 3}$ This statement is consonant with the sources, but cannot be squared with Friedland's own assertion (in 1962/63) that 'until the early 1520s the representatives of the Hanseatic towns attending the Diets, when speaking for public consumption, blandly denied that their co-citizens were engaging in trade with Iceland' or employed diplomatic language to draw a veil over these activities. ${ }^{14}$ Kurt Forstreuter, writing in 1967 about the beginnings of Hanseatic trade with Iceland, only touches on the policy of the Diet in 1434/35, when the Bruges Kontor suggested that the old ordinance forbidding trade with Iceland and the other 
North Atlantic islands should be upheld. ${ }^{15}$ The point of departure for Helge Bei der Wieden's 1994 investigation of Lübeck's Iceland trade is 1468, when King Christian I of Denmark and Norway permitted the Hansards to trade with Iceland. When, after the king's death, the Norwegian Council of the Realm approached Lübeck with an eye to restoring the status quo ante, 'the Diet, in 1482, prohibited trade with Iceland, effective from the following year, but Hamburg, Bremen and Danzig flouted this decree'. ${ }^{16}$ In the most recent revised edition of Philippe Dollinger's Die Hanse (2012), the portrayal of the Iceland trade and the debates it occasioned merit no more than a half a page. This, however, is sufficient to convey a completely false impression of the conflicts surrounding the North Atlantic trade: other than the Diet's prohibition of 1416 (here unaccountably dated to 1417), the work mentions only the Norwegian king's grant of permission (1475) to trade with Iceland directly. Trade with the other islands does not rate a mention. ${ }^{17}$ Justyna Wubs-Mrozewicz, whose topic is the conflicts in Bergen between Hansards (including those sailing from the modern-day Netherlands) and non-Hanseatic Hollanders, implicitly equates the interests of the Bergen Kontor with those of the Hanse, employing the word 'Hansards' when she is writing about the policies of the Kontor. ${ }^{18}$ In 2009, she summarized her view, stating that 'Hamburg and Bremen were especially active in the trade [with Iceland and the tributary islands], which was at times prohibited and at times tolerated by the Hanseatic towns assembling at the Diets (Hanseatic meetings).'. ${ }^{9}$

In short, previous scholarship has left us completely in the dark: what sort of trade in the North Atlantic was permitted (or prohibited), when and by whom is utterly unclear.

\section{Preliminaries: the North Atlantic trade before 1450}

From 1294, German merchants had been forbidden by the Norwegian king to travel anywhere in Norway north of Bergen..$^{20}$ Between 1302 and $1313^{21}$ and again in $1348,{ }^{22}$ this prohibition had been renewed and extended to all foreign merchants. In addition, from 1302, it was forbidden to trade with Iceland or any of the other tributary islands (skattlande) of the king of Norway. The kingdom of Norway was divided into two parts: the mainland (innan lande) on the one hand and the skattlondum on the other, which comprised the tributary islands (skattlande), that is Orkney, Shetland, the Faroes, Iceland and Greenland. ${ }^{23}$ Orkney and Shetland only belonged to Norway until 1468 and 1469 respectively, when they were transferred to the king of Scotland. ${ }^{24}$

Some Hanseatic merchants flouted the prohibition. In 1369 the Diet sent a letter to the Bergen Kontor, which had been established shortly before (1366), stating that forbidden journeys (vørbøden reyse) would be subject to penalty, but did not specify which journeys were forbidden. ${ }^{25}$ Some forty years later, the Diet meeting in Lübeck from 24 May to 3 August 1416 clarified the question, designating sailings to Orkney, Shetland and the Faroes (to Orkenen, to Hytlande unde to Ver) as forbidden sea journeys (zegelacien) (\$89), describing these summarily in $\$ 90$ as journeys to 'Schatland'. These three groups of islands were the only ones to be named in specific prohibitions. ${ }^{26}$ Accordingly, they are the only territories named in the letters the Diet wrote in this regard to the Kontor in Bergen and the council of the city of Reval, notifying them of the prohibition. ${ }^{27}$ It is striking that journeys to Iceland, which the Norwegian crown had equally forbidden, were not prohibited explicitly by the Diet. Such a glaring omission can only have been intentional and suggests that the Diet, by its elegant omission, intended to tolerate Hanseatic trade with Iceland.

Why the Diet did so is difficult to state with confidence. The most likely explanation is that English merchants and fishermen had begun to frequent Iceland in increasingly large numbers at the turn of the fifteenth century and that the Hanse did not intend to concede them this market without a fight. ${ }^{28}$ In any event, merchants from Hamburg, Danzig and Lübeck demonstrably traded with Iceland in the 1420 s. ${ }^{29}$ In 1425 , King Eric of Norway reacted to this breach by directing his officials to indict Germans and other aliens who had recently begun to violate the prohibition of commercial traffic with the tributary islands. ${ }^{30}$ The Bergen Kontor was not in a position to enforce the Hanse's regulations, since it was closed between 1427 and $1433 .{ }^{31}$ For his part, Henry VI of England forbade English merchants in 1432 and again in 1434 to engage in commercial traffic with the Norwegian crown's forbidden areas, in particular Iceland, Finnmark and Helgaland (the latter two lying north of Bergen). ${ }^{32}$

The reason for the English and German merchants' surge of interest in trading with Iceland was presumably the collapse of the cod fisheries of the northernmost Norwegian coast, which was accompanied by a huge drop in stockfish production as a result of the ravaging of the Norwegian population by the Black Death and subsequent plague epidemics in the second 
half of the fourteenth century. This occasioned a surge in the price of Bergen stockfish, ${ }^{33}$ so that Hanseatic and English merchants sought new and cheaper sources of stockfish and found them in trading with Iceland and the North Atlantic island groups, whose catch had hitherto been exported by Norwegian merchants to Bergen, much in the same way Norwegian 'north travellers' had transported to Bergen the cod caught off Lofoten (on the northern stretch of the Norwegian coast). ${ }^{34}$

\section{Interested parties}

Let us begin with dealing with the interests of those involved in the North Atlantic trade who attended Hanseatic Diets. First of all, representatives of those towns who defended the Bergen staple - Lübeck and the Wendisch towns Wismar, Rostock and Stralsund - took part in the Diets. Secondly, representatives of those towns whose merchants were active in the North Atlantic trade, above all Hamburg, Bremen and Danzig, and from the early sixteenth century also Deventer and Kampen. Indeed, even in these towns there were groups who did their best to scuttle the North Atlantic trade of their own fellow citizens. ${ }^{35}$ Advocates and opponents of the North Atlantic trade could exist in the same town at the same time.

Every town council, whose responsibility it was to provide for the common good of the entire town, had to decide at any given point which interests to further and which to impede, in order to maintain the peace and, not coincidentally, its own position at the top of the heap. An abrupt about-face was not unheard of. The Hamburg council, traditionally an advocate of the Iceland trade, forbade the export of grain to Iceland in 1483 following food riots occasioned by a steep rise in the price of grain..$^{36}$ In addition, we have to bear in mind that the town council members also represented the interests of their own families in wholesale and overseas trade, a consideration which must have weighed on their minds as they debated.

A third group attending the Diets consisted of the representatives of towns whose merchants were not active in the trade with Bergen and/or the North Atlantic, but which bought Norwegian stockfish in bulk from the merchants that were active in the North Atlantic trade. These three groups could and did attend the Diets and take an active part in its deliberations.

As a fourth group we must count the representatives of the Hanseatic Kontor in Bergen, whose voice would be heard but who could not participate in the
Diet's policy discussions. However, the Kontor did not speak with one voice, so that we must be aware that the official position trumpeted by the aldermen before the Diet might well diverge from the interests of individual groups of merchants from different towns who were active in the Bergen trade. ${ }^{37}$ Merchants from the Wendish towns on the Baltic, particularly Lübeck, who were resident the year round (the socalled Wintersitzer), dominated the Kontor. ${ }^{38}$ By way of contrast to these year-round residents, the 'summer guests', who only spent a few weeks in the year in Bergen, sailed from Hanseatic towns on the North Sea coast (Kampen, Deventer, Bremen) and from Danzig. In addition, non-Hansards from England and Holland were to be counted among the 'summer guests'. All of them were obliged by the Kontor's statutes to restrict their commercial contacts to the Wintersitzer, trading directly with Norwegians being strictly prohibited. ${ }^{39}$ An additional complication was introduced as the merchants from the Wendish towns withdrew from trading between Bergen and England and Flanders between 1430 and $1490,{ }^{40}$ a development that forced the Wintersitzer to rely on the 'summer guests', particularly those from towns on the North Sea coast, to transport stockfish to the west European markets. All these factors gave rise to severe tensions within the Kontor. ${ }^{41}$ Consequently, we need to bear in mind that the official policies articulated by the aldermen of the Kontor vis-à-vis the Diet and the king of Denmark and Norway were not necessarily consonant with the interests of many of the merchants active in the Bergen trade and resident, at least for part of the year, in the Kontor.

A fifth group attending the Diets were representatives who also belonged to the local corporations of Bergen traders, notably in Lübeck, Wismar, Rostock and Stralsund. ${ }^{42}$ Indeed, the Bergen traders of Lübeck - thanks to their wealth - were such a powerful force that the Lübeck town council, which counted Bergen traders among its members, was, until 1524, as unwilling as it was unable to pursue any policy deleterious to their economic interests. ${ }^{43}$ The sixth and seventh group consisted of the aldermen of the Hanseatic Kontors in London and Bruges. In particular, the London alderman was often obliged to ward off the pressure applied to the Steelyard by the English crown in favour of English Bergen traders, and his counterpart in Bruges had to support the Bergen Kontor in maintaining the staple.

Opinions were divergent enough among those Hansards who belonged to one of these seven groups, but the Diet also had to contend with the discordant 
views of the non-Hanseatic groups which, of course, did not take part at the Hanseatic Diets. First among these - and eighth in our list - was the king of Norway, who from 1380 had claimed and - since the signing of the Union of Kalmar in 1397 - had ruled Denmark (and now and again also Sweden). In particular, this monarch was also lord of the tributary islands. The crown published one ordinance after another intended to regulate the trade of alien merchants in the tributary islands. However, from the Union of Kalmar onwards, most monarchs viewed Norway solely as a source of income and did not take to heart the interests of the populace of Norway or the tributary islands, unless, of course, the crown's income was affected.

As the ninth group we should count the Norwegian Council of the Realm, ${ }^{44}$ which looked out primarily for the interests of its twenty to forty members - the high nobility, the archbishop of Nidaros/Trondheim and the bishops of Oslo, Hamar, Stavanger and Bergen which, on occasion, could coincide with the interests of Norwegian fishermen and the citizens of Bergen. As a constitutional body, the Council of the Realm was formally charged with advising the monarch on all important matters (legislation, granting of privileges, finance, foreign and commercial policy), but in fact only rumbled into activity on the occasion of succession to the throne, particularly when the throne was vacant. With regard to the Low German merchants and the Hanseatic Kontor in Bergen, the Council generally advocated a more restrictive policy, seeking to prevent the English and the Hansards from trading with the tributary islands and, after 1469, to regain Orkney and Shetland for Norway. However, it was seldom successful in prosecuting its interests. Finally, in 1536, the Norwegian Council was dissolved by King Christian III. After that, its function was exercised by the Danish Council of the Realm.

The English were the tenth group. The Hanse had managed to eject them from the Bergen trade almost completely, and consequently they had turned their commercial attention to Iceland. That gave rise to violent conflicts with the Danish governor of Iceland and - increasingly in the fifteenth century - also with Hanseatic merchants engaged in the Iceland trade. The English crown usually supported its own merchants in these conflicts, principally by putting the Steelyard under pressure.

The eleventh group comprised the merchants of the towns of the Netherlands, principally Amsterdam, which did not belong to the Hanse, but whose traders had begun to engage in the North Atlantic trade from the early fifteenth century onwards. ${ }^{45}$

Given the divergent interests of the Hanseatic towns involved and the interests of various groups within those towns, it is easy to understand that finding a consensus was anything but simple. Nonetheless, those attending the Diets had to agree on a common policy toward the king of Denmark-Norway, lest they endanger their rights in Norway and, in particular, their dominant role in Bergen. While so doing, they had to take care to avoid any action which might threaten the economic position of those groups of Hanseatic merchants which were engaged in bitter competition, which often enough turned violent, with the English for mastery of the North Atlantic trade.

\section{The North Atlantic trade as subject of deliberations in the Diets from the second half of the fifteenth century to the 1520 s}

After Eric VII (of Pomerania) had prohibited all alien merchants from engaging in trade with Iceland and the tributary islands in 1425, the North Atlantic trade was, up to 1468 , only debated by the Diet once, in 1434/35, when the Bruges Kontor on the heels of the re-opening of the Bergen Kontor demanded in a petition to the Diet that it took steps to enforce its own prohibition, promulgated in 1416, of commercial ventures to Finnmark, the Faroes, Orkney and other places (Vynlande, Orkenoy, Veroe etc.). ${ }^{46}$ To this, the delegates responded that they would a) discuss the matter in full session, b) inspect the Diet's records and c) consult with the Bergen traders. Whatever they then considered to be in the common interest was to be enforced on Hanseatic merchants in the Kontors in Bruges, London and Bergen. ${ }^{47}$ However, no action seems to have been taken. In the following thirty years, Hanseatic trade with the North Atlantic grew by leaps and bounds as the papers by Hofmeister and Lorenzen-Schmidt in this volume show ${ }^{48}$-, despite the prohibition of the king of Denmark-Norway, which remained in force.

By 1468 at the latest, King Christian I had granted Hanseatic merchants permission to trade with Iceland and the tributary islands. The reason for this reversal of policy was the murder of the representative of the Danish crown in Iceland by English merchants. ${ }^{49}$ In 1468 and 1469 the crown handed over Shetland and Orkney to Scotland as dowry for princess Margaret. Nonetheless, these islands continued to play a role 
in the relations between the Hanse and Norway, since trade with fish from Shetland affected sales of stockfish in Bergen, so that the Diet deliberated the matter intermittently. Following Christian I's death in 1481 the Norwegian Council of the Realm prohibited trade with Iceland and demanded that the Hanse do the same, since Christian I had granted the Hanse permission to trade without consulting the Council. ${ }^{50}$ Consequently, the aldermen of the Bergen Kontor attended the Diet in 1482 and complained about direct trade with Iceland, underscoring the damage it wreaked on the Kontor. Since Hamburg's merchants were the principal culprits, its representatives were obliged to withdraw while the remaining representatives deliberated about what to do. ${ }^{51}$ The upshot was that Hamburg's representatives were informed that its merchants were to desist from trading with Iceland, but that any ships which had already been loaded with cargo destined for Iceland could nonetheless sail forth. The Diet required Hamburg's representatives to bring the matter before the town council, so that the next Diet could debate a prohibition of the Iceland trade. ${ }^{52}$ This was the beginning of the faintly absurd Hanseatic deliberate confusion concerning the interdiction of trade with Iceland, to which we must now turn. A precise analysis of the positions of the actors is not simplified by the utter inability of the Danish crown to stick to one policy. Although King Hans bound himself in the course of negotiations with the Councils of Norway and Sweden in 1483 to interdict Hanseatic trade with Iceland, ${ }^{53}$ he granted the Hollanders a privilege in 1490, ensuring them of the same rights of free trade in Iceland that the Hansards enjoyed (!), and permitted the English to trade freely with Iceland for seven years initially. The same obtained for trade with the tributary islands. ${ }^{54}$

In 1484, one year after King Hans' prohibition of Hanseatic trade with Iceland (which, however, was not made public, only having been promised to the Council of the Realm and only known to us through the Council's letter to the Bergen Kontor $^{55}$ ), the Diet decided to prohibit the trade itself. Hamburg's representatives objected that they had not permitted a single ship destined for Iceland to be loaded with cargo in the Elbe, elegantly, if disingenuously neglecting to respond to the complaint of the Bergen Kontor that Hamburg merchants had loaded just such ships destined for Iceland in Wismar. Moreover, Hamburg's representatives continued, their council had given them no instructions regarding the Iceland trade, a position which other town representatives also put forth. The
Diet could only agree to write to Bremen, Danzig and other towns in which cargoes destined for Iceland were loaded, requiring them to interdict the trade. The letter to Danzig has survived, and, in closing, it notes that the Norwegian Council had threatened to revoke Hanseatic privileges in Norway if the Hanse failed to close down the trade with Iceland, Shetland and the Faroes. ${ }^{56}$

In 1486, representatives of the Bergen Kontor employed, for the first time, the argument ${ }^{57}$ that the debt system which governed the commercial relations between year-round Hanseatic residents in Bergen and Norwegians transporting stockfish there for sale (an arrangement very much to the advantage of the Wintersitzer) would collapse if Hanseatic merchants bought dried fish in Shetland and the Faroes. Since the Shetland and Faroese fishermen who customarily transported their stockfish and other goods to Bergen had built up massive debts owing to the Wintersitzer (Hanseatic merchants resident in Bergen the whole year round) for goods (such as grain, flour, beer etc.) which had been sold to them on credit the previous year, debts which were payable in dried fish in the following year, the Wintersitzer could forget about being paid back if the fishermen sold their goods to other Hansards trading directly with the tributary islands. Note, however, that we do not know how often this occurred and what damage was wreaked. Note, too, that no mention is made of Iceland in this context. ${ }^{58}$ The Hamburg and Danzig representatives in the Diet declared themselves very ready to bring the Kontor's complaint before their respective town councils and expressed their confidence that if other towns prohibited direct trade with Shetland and the Faroes, Hamburg and Danzig would follow suit.

These discussions set the pattern for the Diet's deliberations in 1487 and 1489, with one small difference. The argument was now presented that fish caught in Iceland was never transported to Bergen, so that direct Hanseatic trade with Iceland could not possibly have a deleterious effect on the Bergen staple, ${ }^{59}$ and furthermore that the English were active in the Iceland trade, so that it would be unjust to forbid Hanseatic merchants from trading there too. ${ }^{60}$

Just how hypocritical the arguments of Lübeck's representatives in favour of a blanket prohibition of the Iceland trade in fact were, was revealed in 1489, when the representatives of Rostock, Stralsund, Wismar, Lüneburg and Lübeck resolved to interdict sailing to Iceland completely: no ship destined for Iceland would be permitted to leave their harbours and none of their citizens would be allowed to sail there from any other 
harbour. This resolution, however, carried the revealing rider that it would only come into effect if Hamburg followed suit. Once again, Hamburg's representatives were directed to bring the matter before the town council, which was to respond as soon as possible. ${ }^{61}$ This was nothing but a smoke-screen. Shortly beforehand, Hamburg had publically proclaimed a bye-law requiring that all ships destined for Iceland depart from Hamburg and bring their return cargo back there. ${ }^{62}$ There can be little doubt that this bye-law was well known to those attending the Diet, in particular to Lübeck's representatives. The conclusion can only be that the Wendish towns knew perfectly well that Hamburg would never agree to a prohibition, so that their resolution, to all appearances a strict interdiction of the Iceland trade, in fact sanctioned it, without actually admitting to the fact.

Continuing the charade, the Diet of 1494 - meeting in Bremen, no less, and attended by representatives of Hamburg and Danzig, the merchants of all three towns being major culprits - renewed the Hanseatic interdiction of 1416, prohibiting trade with Shetland and the other islands and threatening all malfeasants with loss of their rights under Hanseatic privileges and ejection from any and all Hanse towns. ${ }^{63}$ No one objected to this resolution, and indeed it was repeated in $1525 .{ }^{64}$ Elegantly, the Iceland trade was not mentioned at all, just as had been the case in 1416 .

Needless to say, the prohibition proved to be unenforceable. This, however, did not mean that Hanseatic merchants could openly load cargo destined for the Faroes (to take but one example) in a Hanseatic harbour, since this trade had been prohibited by the Diet and, in any event, the merchants would have to reckon on the king of Norway's having dispatched observers who reported back to him. In 1498, the aldermen of the Bergen Kontor described how this trade, albeit officially forbidden, was in fact conducted by subterfuge. ${ }^{65}$ Skippers intending to sail to one of the forbidden islands obtained letters from one prince or another - Duke Frederick of Holstein and the Count of Oldenburg are cited here as examples - and departed from harbours in the county of Holstein or in Frisia. Everything was seemingly above board, except for the fact that citizens of Hanseatic towns had fitted out the ships and that the return cargoes were sold on markets in Hanseatic towns. In this particular case, a merchant of Bremen had bought stockfish (of the grade called rotscher) year for year in Shetland and brought it back to Bremen, Stade and other towns, which ruined the trade in good stockfish of the same grade from northern Norway.
During the following eight years, the Diets did not discuss the North Atlantic trade at all. In 1507, however, renewed deliberations were sparked off by Deventer and Kampen, whose representatives employed the price argument for the first time, objecting to the stockfish trade with Shetland because rotscher could be bought there very cheaply indeed and sold for a thief's bargain on Hanseatic markets, thus undercutting the price of good rotscher from Bergen. ${ }^{66}$

The fact that trade with Iceland was an accepted fact in Hanseatic circles is demonstrated by the resolution of the Diet meeting in Lübeck in 1511, which stated baldly that Hanseatic merchants should be warned against attacking the English, either in Iceland or offshore. ${ }^{67}$

In the course of negotiations in 1513 in Copenhagen, Lübeck's quarters witnessed discussions between the king of Denmark and the Hanseatic Bergen traders. The latter complained that merchants from Hamburg, Bremen and Holland were trading with Iceland and the other tributary islands, much to the detriment of the Kontor. The king replied that the Hollanders should cease to trade with these areas and that merchants from Hamburg and Bremen who frequented the islands should ship their dried fish to England. Thus did the 'England clause' make its debut in Hanseatic sources. It goes without saying that the towns affected protested, pointing out that they had been free to trade with these areas for some time without being forced to detour to England. ${ }^{68}$ On 12 August 1513, King Christian II presented an official demand that the Wendish towns cease exporting Icelandic dried fish to Hamburg and other places. ${ }^{69}$ However, the Diet does not seem to have promulgated a formal interdict.

The Danish king's initiative had no effect whatsoever. The very next year, the representatives of the Bergen Kontor presented the diplomats negotiating in Oslo with a schedule of complaints, specifying among other things that Hamburg sent six to ten ships per annum to Iceland which brought dried fish back to Hamburg and that merchants from Bremen and Holland were imitating them and shipping their cargoes of fish back to Bremen and Amsterdam. As a result, demand for dried fish from Bergen had collapsed. Not only that, towns in the interior of Germany (the so-called overlender) had developed a technique of softening the texture of Icelandic dried fish using watermill-driven mallets, so that they preferred it to Bergen stockfish. Finally, the Iceland traders' costs were lower, since they could fit more fish into three ships than the Bergen traders could in five and they did not have to bear the burden of financing a permanent Kontor. ${ }^{70}$ 
In 1515, Christian II formally threatened anyone not transporting Icelandic dried fish in the accustomed manner to England with the loss of all privileges and exclusion from all harbours in his realm. ${ }^{71}$ But this had no effect whatsoever. Bremen's representatives at the Diet of 1517, for instance, declared that their town would agree to cut off trade with Iceland, provided the other towns did the same, and that they would surely bring the matter before the Bremen council, in the expectation that it would fulfil the Diet's expectations by issuing an appropriate ordinance. ${ }^{72}$

In 1517, the aldermen of the Bergen Kontor argued that those who flouted ancient custom were only out for their own gain, to the detriment of Hanseatic merchants in general and the Kontor in particular. ${ }^{73}$ In 1518 , the Diet deliberated on the question of the Iceland trade, although no new arguments were brought forth. ${ }^{74}$ However, the London Steelyard did enter the debate, complaining that the conflicts between Hansards and Englishmen in Iceland were damaging AngloHanseatic relations and, in particular, endangering the status of the Steelyard. ${ }^{75}$

In 1519, the Bergen traders placed the dangers facing the Bergen Kontor in the broader context of the insecurity of all Hanseatic trading stations overseas. The Diet demanded of Hamburg that it bear the common good in mind, since the Kontor in Novgorod, which had in the past proved to be most profitable to the Hanse towns, had been abolished, the English Kontor was in grave danger and the Bruges Kontor had been weakened. Consequently, the destruction of the Bergen Kontor was simply not to be countenanced. Hamburg's reply, as ever, was only a very few ships exported dried fish from Iceland to England and fewer still to Hamburg, and that only if a storm drove the ship into the Elbe. It was to be borne in mind that Hamburg's citizens did export beer and other merchandise, and it was only fair that they be permitted to import return cargoes. That, surely, could have no deleterious effect on the Kontor. At this point, the central argument followed, one which can only be properly understood against the background of recent advances in Hanseatic scholarship, namely the revolution in the understanding of the constitution of the Low German town and the unique legal constraints of 'concurrence law' (Einungsrecht). Hamburg argued that, although the town council would like to enact laws embodying the Diet's recommendation, this would be impossible, since Hamburg's citizenry would not countenance such a step. Indeed, there had been riots occasioned by just such initiatives in the recent past. ${ }^{76}$ In making this argument, Hamburg elegantly passed over the uncomfortable fact that, although the Iceland trade had been the cause of the unrest in 1483, the issue at hand was that it should be ended and not sanctioned. ${ }^{77}$ After other Hanseatic representatives had added their opinions to Hamburg's, the Hamburg representatives were asked to leave the room while the remaining delegates hammered out a compromise. ${ }^{78}$ That having been done, the mayor of Lübeck informed the Hamburg delegates of the resolution: the town council of Hamburg should bear the common good in mind and regulate the Iceland trade in the manner in which the Diet had envisaged, namely to require its merchants to export Icelandic dried fish solely to England. If a ship were to be driven into the Elbe by storm, then the cargo should be sent to England and not sold in Hamburg under any circumstances. Possible losses by one merchant surely could not be more significant than the damage to all. Hamburg should acceed to the Diet and cleave to its resolution. Hamburg's representatives replied that they were happy to bring the matter before their fellow council members but wished to point out that it was not right to reproach them with something that the Diet of Bremen had permitted (nagegeven) in 1494. ${ }^{79}$

Half a year later, in October 1519, the Diet launched another attempt to reach a binding decision on the Iceland trade as it affected the Bergen Kontor, this time by arbitration. Once again, Hamburg's representatives claimed to be insufficiently instructed, so that they could not agree to such a procedure, and in any event the citizenry would refuse to break off the Iceland trade, simply because they had to earn a living. Worse yet, Hamburg's merchants were treated badly in Bergen, having to pay higher dues to the Kontor than merchants of any other town. Despite this protest, neutral arbiters from Lüneburg and other, unnamed towns were appointed, because the Diet felt that the common good outweighed individual advantage. Predictably, Hamburg's representatives refused to accept the verdict of the arbiters, but promised to bring the matter before the town council with a view to appointing negotiators with due dispatch who would travel to Lübeck to deliberate with the Bergen traders in the matter. ${ }^{80}$ However, there is no trace in the sources that such a delegation was ever appointed or arrived in Lübeck.

In 1520 and 1521 the conflict with the English intensified. The English complained that the Hansards not only denied them free access to Hanseatic towns, but also drove them out of neutral areas such as Iceland. ${ }^{81}$

In view of the monotony of the arguments put forward in the Diets, namely that Icelandic dried fish could only be shipped to England, to which the 
representatives of Bremen and Hamburg invariably replied (for instance in 1521) that they had no instructions to agree to such a regulation, ${ }^{82}$ it is noteworthy that in 1523 the Lübeck fleet, sailing off Sweden, was victualled with Icelandic fish. ${ }^{83}$

In 1524, the cards were shuffled anew, which, given the previous history of relations, is perhaps not altogether surprising. In the course of negotiations which took place that year in Copenhagen, the Lübeck Bergen traders presented the town council with a draft of a Danish privilege for the Hanse. The secretary of the Lübeck town council, Paul vam Velde, declared himself satisfied with all clauses. However, he stated, the Iceland trade should be permitted, given the good relations between Hamburg and the Danish crown. ${ }^{84}$ It took just a year for Hamburg, Bremen and Danzig to bring the rest of the Hanse around to their point of view. The mayor of Lübeck, citing a mandate of the Diet, informed the aldermen of the Bergen traders that they would have to accept the Iceland trade. ${ }^{85}$ The reason was that the Diet had become confident that tolerating the Iceland trade, as long as it was not done openly, would pose no threat to the economic or legal position of the Bergen Kontor. In consequence no one attending the Diet in 1525 supported the Bergen traders' petitions, which was nothing less than a complete aboutface. Indeed, the representatives of the Hanse towns directed the Bergen traders to come to a peaceful solution to the problem of direct trade with Icelandic fish, although the issue remained controversial. In regard to the Shetland trade, the interdiction of the Bremen Diet of 1494 was renewed. Despite this, the Bremen representatives interjected that it was better to bring dried fish from Shetland directly into the Hanseatic towns rather than making a detour around to Bergen, particularly since Shetland fish was only intermixed with other sorts there. ${ }^{86}$ As was usual, the interdiction was neglected.

The Diet of 1525 marked the effective end of the endless debates about the North Atlantic trade in Hanseatic assemblies. Certainly, the matter cropped up from time to time until $1535,{ }^{87}$ whenever the Bergen traders made a complaint, but the true state of affairs is unmistakably signalled by the fact that in 1535, despite the fact that the interdiction was at least formally in force, Hamburg and Bremen complained about obstruction of their North Atlantic commercial ventures, Hamburg with regard to trade with Iceland and the Faroes, and Bremen with regard to trade with Iceland and Shetland. ${ }^{88}$ This quite possibly could indicate that both towns had divided the North Atlantic into two zones of interest. Hamburg's influence with the Danish-Norwegian monarchs, which the secretary of the Lübeck council alluded to in 1524, would seem to have been considerable, since in 1533 the mayor of Hamburg announced to the Diet that two Hamburg merchants had been acting as representatives of the Danish king on the Faroes since $1531 .^{89}$ In the following years, the trade with Iceland, Shetland and the Faroes occasioned no more debates in the Diet. The last issue to cause difficulties was trade north of Bergen, in particular with Trondheim..$^{90}$

That exhausts the published volumes of the protocols of the Diet. The Cologne and Danzig inventories (which run up to 1591) contain only two stray references to the Iceland and Shetland trade, neither of which deals with the question of whether trade was permitted or prohibited. Nor do the substantial records of the Bergen Kontor in the Lübeck town archive contain any traces of debates on this question, ${ }^{91}$ and the same is true of the holdings of the archive in regard to the Diets after 1537.

\section{The policies of the delegates to the Diet}

Let us begin with the arguments of the participants in the debate. The aldermen of the Bergen Kontor and the corporation of Bergen traders in Lübeck warned, from 1484 onwards, that permitting the direct importation of stockfish from Iceland into Hanseatic towns would destroy the Kontor, because Icelandic dried fish was cheaper, albeit of lower quality. It was cheaper because the Iceland traders could load more fish per ship (meaning that their ships were larger) and because they did not have to support a permanent Kontor financially. The difference in quality, which initially redounded to the commercial advantage of Bergen stockfish, was erased by the development of water-driven mallets in the Rhineland and in Westphalia which softened the texture of tough Icelandic dried fish. Reports indicate that this technological innovation led to an increase in demand for Icelandic fish, to the detriment of Bergen stockfish. From 1486 onwards, the Bergen Kontor and the Lübeck Bergen traders also put forward the credit argument, namely that the purchase of fish in Shetland, the Faroes and perhaps also in Iceland would destroy the credit system in Bergen, since the Hanseatic Wintersitzer would not be paid in fish for the goods they had advanced on credit, to their utter destruction. ${ }^{92}$ Since direct trade with Iceland had been forbidden by the Danish-Norwegian crown since 1513, 
they warned that any violation could give the king an excuse to suspend or even rescind the Kontor's privileges. The aldermen of the Kontor and of the Lübeck Bergen traders made much of the fact that they were furthering the common good (although the advantages of the policies they advocated would in fact only accrue to the Hanseatic merchants resident in Bergen the whole year round), which surely should not be sacrified to mere 'private' gain. Even if their opponents refused to see the light, it was better for a few merchants to suffer disadvantages than for all to be destroyed. ${ }^{93}$

Merchants from Danzig, Hamburg and the Hanse towns on the Zuijderzee complained about discrimination in the Bergen Kontor. They declared themselves to be ready and willing to cease trading with the North Atlantic islands if only they were treated as the equals of merchants from the Wendish towns in Bergen. This, despite the fact that they knew very well indeed that this condition would never be fulfilled. The Iceland trade, Hamburg and Bremen argued, had been free to all Hansards since time immemorial, and consequently, Hamburg argued further, the town council was simply not in a position to prohibit it, in particular since other nations continued to trade with Iceland. Not to mention the fact that very few ships sailed to Iceland, of which (as Hamburg argued after 1515) none traded directly between Hamburg and Iceland. Consequently, the restriction of the Iceland trade to exports to England was unacceptable.

Bremen's main argument was that the town had but few ships and that its merchants could only sell dried fish from Shetland in areas where no stockfish from Bergen was to be found or where it was too expensive. This was a fairly bold argument, when one considers that Icelandic stockfish was said to endanger the sale of dried fish from Bergen because it was cheaper.

The Diet generally took sides with the Kontor, emphasizing that the common good was more important than individual profit. That was a noble sentiment, but it dissemblingly failed to take account of the fact that merchants from various Hanse towns competed against one another in numberless other markets. Despite the brave front it put up in public in favour of the Bergen Kontor, evidently actuated by the strong position of the Lübeck Bergen traders in the fifteenth century, there are some indications that even the Lübeck town council winked at the North Atlantic trade. ${ }^{94}$

Older research saw the Diet as embodying the 'unity' of the Hanse. It was viewed as a legislative institution which could issue prohibitions which had the force of law for all Hanseatic towns and merchants. That view of the Hanse's constitutional has not found favour in modern scholarship. The Diet governed not merely by the consent of the governed, but solely and exclusively by the complete unanimity of the representatives of its member towns. It witnessed frequent, wearying debates, with arguments being put forth again and again in the hope of reaching a compromise which could be embraced by all, but often enough the Diet was forced to admit to itself that the issue at hand could not be resolved and a consensus could not be reached. No town could be coerced to agree to a measure it did not want to accept. ${ }^{95}$ The pattern established in 1484 regarding the prohibition of the Iceland trade and repeated again and again thereafter suffices to demonstrate this.

The reason for the failure to agree was the fierce competition between groups of merchants of the individual Hanse towns. In this light, the achievement of the Diet is impressive, since it managed to settle bitter conflicts between towns and their groups of merchants peacefully.

\section{What were the consequences of diverging interests?}

From the early fifteenth century onwards, the Norwegian crown, the aldermen of the Bergen Kontor and the Lübeck Bergen traders were all in agreement on the need to preserve the Bergen staple and to prohibit trade with the tributory islands and the mainland regions north of Bergen. The Diet concurred as far as the prohibition of trade was concerned, but shied away from an explicit interdiction of trade with Iceland. The resolution of $1416^{96}$ and both of the Diet's surviving letters in this connection, directed to the Bergen Kontor and the Reval town council, only mention trade with Shetland, Orkney and Faroe..$^{97}$ The Iceland trade, although it consistently featured in the interdicts of the Norwegen crown along with the three island groups, was not explicitly forbidden. One can only conclude that the Diet's reticence was intentional: it meant to wink at the Iceland trade all along. ${ }^{98}$

While the Danish-Norwegian crown, the English monarchy and the Diet agreed that trade with Shetland, Orkney and the Faroes should be restricted to Norwegian merchants, trade with Iceland was not explicitely prohibited by the Diet. Only the English crown recognized the Norse prohibition of trade with Iceland and enforced it, at least officially, while the Diet quietly refused to take note of it. The Diet could, of course, fall back on the flimsy argument that Iceland 
had been subsumed under the schatlande, trade with which $\$ 90$ of the resolution of 1416 had prohibited. Even if Iceland was not explicitly named there, the Diet could argue to the Danish-Norwegian crown that the Hanse had indeed publically proclaimed an interdiction of trade. The Diet's two-faced policy on the Iceland trade placed Hanseatic merchants in a difficult position. If they were caught trading with Iceland, they were liable to severe penalties from the Danish-Norwegian crown, but the Hanseatic towns regarded such commercial ventures as blameless. When one considers the draconian penalties with which the Diet threatened those who flouted its prohibition of trade with Shetland, Orkney and the Faroes, namely that malfeasants were to forfeit all rights under the Hanseatic privileges, their ships and merchandise to be seized, ${ }^{99}$ the fact that the Diet turned a blind eye to the Iceland trade can only be interpreted as a veiled invitation to engage in it. ${ }^{100}$

Subverting the interdiction of the Iceland trade meant, however, that while the Diet never tired of proclaiming its complete agreement with the Bergen Kontor on the issue of the North Atlantic trade, it in fact did not see eye to eye with the Kontor. The Diet's ringing statements, destined for public consumption, were in fact designed to mollify the Danish-Norwegian crown so as to avoid endangering the Hanseatic privileges. Since, however, Hamburg consistently claimed the right to trade freely with Iceland as its due and, whenever the matter was broached in a Hanseatic assembly, be it a full Diet or a meeting of the Wendish towns, blandly offered to bring the matter before the town council in the expectation that it would fall into line with the rest of the Hanseatic towns, a blanket prohibition of the Iceland trade was destined to remain a pious hope. No measure could be passed unless all Hanseatic representatives were in agreement, which Hamburg was manifestly not. To complicate matters yet further, the Danish-Norwegian crown proved utterly unable to stick to one policy. King Christian I had permitted the Iceland trade in 1468, whereas King Hans (1481-1513) had promised the Norwegian Council of the Realm that he would prohibit Hansards from trading with Iceland, but, in pursuing this antiHanseatic policy, had granted the Hollanders in 1490 the same rights to trade freely with Iceland which the Hansards enjoyed. ${ }^{101}$ Again, in 1513, when King Christian II issued a further interdiction of direct trade with Iceland, Hamburg's representatives objected that the restriction requiring Hansards to export Icelandic dried fish solely to England was unacceptable, since it had never been enjoined on Hanseatic merchants.
However, they were more than happy to bring the matter before the town council in the expectation, thus scuttling any resolution on the matter.

It is not easy to avoid the conclusion that the Diet was not secretly pleased at the arguments Hamburg, and indeed Bremen and Danzig put forward, since they left the door open for merchants from those towns to engage in trade with Iceland, albeit at their own risk, should they be caught by the Danes or Norwegians. The crucial point was that these arguments served to ameliorate the intense conflicts within the Bergen Kontor itself which had arisen because of the Bergen Kontor's policy of savage discrimination against merchants from Hamburg, Danzig and the Zuiderzee towns. Consequently, the home towns of the victims argued that they would be more than willing to prohibit the Iceland trade, provided their merchants were vouchsafed fair and equal treatment in Bergen. Viewed from a somewhat longer perspective, the most disturbing aspect of this conflict was that it made it apparent that no one was willing to sacrifice his own economic interests: Bergen traders from the Baltic towns remaining in Bergen the year round defended their private monopoly in Bergen against fellow Hansards, and Iceland traders from the North Sea towns pursued their interests in Iceland irrespective of the damage this might wreak upon the Bergen Kontor. This, surely, is a major reason for the death of the Hanseatic trading system - based as it was on cooperation between overseas Kontore and home staples - in the sixteenth century.

The moment the Diet realized that the flowering relations between Hamburg and the Danish-Norwegian crown made it inopportune to maintain the official policy of prohibiting the Iceland trade, it dropped it in 1525 , requiring the Bergen traders to seek a peaceful resolution of the conflict and cease obstructing the Iceland trade. At that point, trade with Iceland and the other North Atlantic island groups dropped off the Hanse's radar screen, returning only fitfully in the next ten years and then disappearing altogether. The Iceland trade was tolerated, while trade with Shetland, Orkney and the Faroes, although officially prohibited, continued unimpeded.

What is the lesson to be learned? The Hanseatic Diet was constitutionally incapable of ordering anyone about, and no majority, however impressive, could out-vote the rump, compelling its adherence to a resolution. As was the case with many other medieval political institutions, Hanseatic Diets were distinctly unregimented gatherings, very different in character from modern legislative bodies in parliamentary democracies, which 
sought to find a consensus among all those present, by postponing discussion of issues which proved to be too controversial. This characteristic, which the Hanseatic Diets shared with their Imperial counterparts, gave rise to Johannes Helmrath's felicitous observation regarding the Imperial Diets of the late fifteenth century that 'To meet is often to postpone' (Tagen bedeutet auch Vertagen) ${ }^{102}$ Hanseatic Diets were forever on the search for a compromise which could be accepted by as many representatives as possible, but had to accept the bitter fact that a resolution was impossible if the interests of member towns were diametrically opposed. In situations such as this, it was essential to lull those foreign powers who had granted privileges to the Hanse - and could therefore, given the excuse, suspend or rescind them (in this case: the Danish-Norwegian crown) into a false sense of security, loudly proclaiming that the Hanse was doing everything in its power to punish violations of its prohibitions (such as trade with the North Atlantic islands), while in fact turning a blind eye to them or, in the case of the Iceland trade, actually excluding the possibility of penalizing anyone.

\section{A conclusion in seven points}

1. In principle, the Hanse had prohibited trade with Shetland, Orkney and the Faroes since 1416. The penalties the Diet had foreseen for those who violated its interdiction were, however, never imposed, so that the prohibition was honoured principally in the breach. Unfortunately, the sources do not even allow us to guess at the dimensions of the commercial exchanges. The Hanse never tired of explaining to the Danish-Norwegian crown and the Norwegian Council of the Realm that it was doing its uttermost to flank the Scandinavians' prohibitions with corresponding decrees of its own in order to force its merchants to comply.

2. Internally, the Hanse had turned a blind eye to the Iceland trade since 1416. Since the Hanse had never prohibited these commercial ventures or threatened those trading with Iceland with any penalty whatsoever, merchants were free to trade with Iceland at their own risk. Not even the 'England clause', which in 1513 mandated that Hanseatic merchants could only export Icelandic fish to England, was ever publically proclaimed by the Diet. The Diet thus left the door open for the Iceland trade, claiming all the while to the Danish-Norwegian crown that Iceland was subsumed under the schatlande, trade with which was prohibited, in $\$ 90$ of the resolution of 1416. In 1494 and 1524 the Diet cited this resolution in its arguments.

3. The consequence of this two-faced policy was that merchants from Hamburg, Bremen and Danzig who made up the bulk of the 'summer guests' to whom the year-long resident Bergen traders from the Wendish towns denied equal rights - and merchants from Wendish towns wishing to take part in the North Atlantic trade were free to trade with Iceland, albeit at their own risk. Trade with Shetland, Orkney and the Faroes, while officially prohibited by the Diet, was covertly conducted from non-Hanseatic ports. The Diet never took any serious steps to prevent it.

4. The Diet was forced to prohibit trade with Shetland, Orkney and the Faroes, since it felt obliged to uphold the monopoly of the Bergen Kontor and the credit system governing the stockfish trade there, which was much to the advantage of the Bergen traders resident in Bergen the whole year round. To do otherwise would have endangered the Kontor's privileges.

5. The Iceland trade is a puzzle. The commercial links between Iceland and the Danish-Norwegian staple in Bergen and the Hanseatic Kontor seem to have been weaker than those between Bergen and the North Atlantic islands, or at least to have become weaker in the course of the fifteenth century. Consequently, the Diet became more and more confident that tolerating the Iceland trade, as long as it was not done openly, would pose no threat to the economic or legal position of the Kontor.

6. Punishing merchants who engaged in the officially forbidden trade with the North Atlantic islands proved to be unfeasible, since there were only two bodies which could discipline them. First, while the Bergen Kontor was very much in a position to do so, no merchant trading directly with the North Atlantic islands had ever gone there. Second, while the home towns of the North Atlantic traders and skippers might have exacted penalties, they were simply not interested in doing so, as the silence of the sources demonstrates. For the town councils of Lübeck and the other Wendish towns, preserving the privileges of the Bergen traders was paramount: hence their public show of support for the prohibitions of the Danish-Norwegian crown. Nonetheless, they kept the door open for merchants from other Hanseatic towns to forge commercial links to the islands of the North Atlantic by tolerating the Iceland trade and neglecting to demand the 
punishment of merchants who traded directly with the other island groups.

7. Ultimately, the central task of the Diet was to promote the commercial success of all Hanseatic merchants. Everyone wanted a piece of the cake but, in view of the diverging interests of the towns and the groups of merchants within their walls, this could only be achieved by deception. The policies actually followed outside of the public gaze in fact subverted the purported intentions of the Diet, such as they were trumpeted abroad for the delectation of the Danish-Norwegian crown, the Norwegian Council of the Realm and the Hanseatic Bergen traders. The necessity of drawing a veil over what was really happening explains why the Diet insisted on the confidentiality of its deliberations, to the extent that in 1518 towns which were too dependent upon their titular lords to refuse them information about the internal discussions of the Diet were excluded from participation, although they continued to enjoy their rights under the Hanse's privileges when trading overseas. ${ }^{103}$

\section{Endnotes}

* I am very grateful to Stuart Jenks who translated my paper into scholarly English.

${ }^{1}$ I use the term 'North Atlantic trade' to denote trade with Iceland and/or the other groups of islands, exclusive of the trade with Bergen.

2 Sources will be cited in the text headed 'Preliminaries'.

${ }^{3}$ For the sake of simplicity, I employ the terms 'king of Denmark-Norway' and 'Danish-Norwegian crown' in the context of the North Atlantic trade from the late fourteenth century.

${ }^{4}$ Pitz 2001; Schipmann 2004.

${ }^{5}$ Nedkvitne 2014, 314f.

${ }^{6}$ King Magnus forbade again trade by alien merchants north of Bergen and to the tributary islands in 1348; Ræstad 1912, 44-47; Taranger 1904, 100f, with reference to NGL III, 170. I am grateful to Pétur Eiríksson, Iceland, for this hint.

${ }^{7}$ DI IV, 324 et seq.; see also DI XVI, $258 \mathrm{f}$.

${ }^{8}$ Burkhardt 2009, 139ff.; Nedkvitne 2014, 39-53, 111-145; Wubs-Mrozewicz 2008, 105.

${ }^{9}$ See n. 34 below.

${ }^{10}$ Baasch 1889, 13. He was astounded by the contrast between these interdictions and the complaints of English merchants in 1486 to crown and parliament that the Germans dominated the Iceland trade completely (for the complaint of the English see HR III, 2, no. 31, p. $32)$. On the following pages, Baasch returned again and again to Hamburg's role in the Diets after 1485, failing, however, to mention the results of the attempts to find a consensus: ibid., 14-19. Only when discussing the meeting of the Wendish towns in 1489 (HR III, 2, no. $270, \mathbb{S} 28,30$ ) did he note that the other towns made Hamburg's actions a condition of their own policies: ibid., 15.

${ }^{11}$ Bruns 1900, LXVI; HR III, 1, no. 365, $\$ 42$.

${ }^{12}$ Bruns 1900, LXVII; this interdiction was not yet published in 1900; Bruns cites in note 5 a collection of Hanseatic statutes dating from 1604, which he alleges rightly to be in the collection of the National Library of Copenhagen; it is 'Hansici Foederis Leges et Statua sive Compendium Recessuum', f. 22v., 'nota' to $\$ 19$, Den Arnamagnæanske håndskriftsamling AM 296 fol; the Rezess from 1521 is meanwhile published in HR III, 7, no. 413, $\$ \$ 143-146,719$.

${ }^{13}$ Friedland 1995b, 192 et seq.; ibid., 193 writes that the Diets of 1487 and 1489 promulgated a conditional prohibition of the Iceland trade, 'this being, by the way, the first and only Hanseatic interdiction of the Iceland trade which was ever passed'. One must, however, note that there was no such thing as a 'conditional prohibition' (see below).

${ }^{14}$ Friedland 1995a, 160; for examples of exquisite diplomatic formulations see ibid., 160f. - Friedland also states that the Bergen Kontor 'presented its complaints about the illegal trade with the islands to the Diet in wearying monotony - indeed to the point of complete ineffectuality - until 1535' and that 'the short-lived attempts of the Danish crown [...] to enforce the old prohibition of trade with Iceland' were equally ineffectual. This was particularly true of its attempt to 'force sales of Icelandic fish onto the English market, in order to protect the sales of Bergen fish on the continent'. Accordingly, he notes, the Diet of 1518 expanded the prohibition to include Shetland fish: Friedland 1995b, 193 and 203, n. 21.

${ }^{15}$ Forstreuter, 1967, 117 (HR II, 1, no. 393, \$12, 394, \$10, p. 318 et seq.; $D I \mathrm{~V}$, no. 12). In this resolution the word 'Vynland' was used, which Friedland feels is a scribal error for 'Hynland' = Iceland (Friedland 1995b, 192), while for Nedkvitne it refers most probably to Vinland, the Norse name for a settlement in Newfoundland (Nedkvitne 2014, 476, n. 903; on this see n. 46 below).

${ }^{16}$ Bei der Wieden 1994, 11. On the following pages, he introduces further distinctions. In order not to disadvantage their citizens, the Wendish towns permitted direct trade with Iceland in 1489, despite the opposition of the Lübeck Bergen traders; the sources, he states further, speak repeatedly of prohibitions which were floutet and stress the fact that the Lübeck council tolerated the Iceland trade, yet drew a veil across this policy in order to preserve the peace within its walls. That, he says, is the reason that Lübeck's Iceland trade does not leave a trace in the records of the Diet (ibid., 12). - The great value of Bei der Wieden's work is the detailed treatment of the Iceland trade in the period after the 1530s, which is beyond the scope of this paper. ${ }^{17}$ Dollinger 2012, 318.

${ }^{18}$ Wubs-Mrozewicz 2008, 105, n. 1. The trade with Iceland and the other island groups in the North Atlantic is treated here almost exclusively in regard to the role of 
the non-Hanseatic Hollanders and only occasionally in regard to the role of the Hanse towns in the east of the present-day Netherlands, specifically in the Overijssel region: ibid., 71, 152ff., 183-188, 212ff. (concerning Hollanders), 180ff., on the Overijssler.

${ }^{19}$ Wubs-Mrozewicz 2009, 199.

${ }^{20}$ HUB 1, no. 1114 and 1115; HR I, 1, 63; DN V, no. 21 and 23; Norske middelalderdokumenter, no. 41; Nedkvitne 2014, 307.

${ }^{21}$ NGL III, no. 53; Norske middelalderdokumenter, no. 59; HUB 2, no. 18; Nedkvitne 2014, 310.

${ }^{22}$ NGL III, no. 83; HUB 3, no. 136 (pace Nedkvitne 2014, no. 13).

${ }^{23}$ Sigurðsson 2010, 49-73, 62ff.; Wærdahl 2011, 69ff.

${ }^{24}$ Wærdahl 2011, 7.

${ }^{25}$ HR I, 1, no. 511; NGL II, rk I, no. 346, $\$ 11$.

${ }^{26}$ HR I, 6, no. 262, art. 89-92, pp. 216ff.; NGL II, rk. I, 662ff.

${ }^{27}$ HR I, 6, no. 275; NGL II, rk. I, 662ff. (to the Bergen Kontor); HR I, 6, no. 276 (to Reval).

${ }^{28}$ Karlsson 2000, 118-122; Starkey, Reid and Ashcroft 2000; Gelsinger 1981; Childs 1995, 11-31.

${ }^{29}$ Hofmeister 2000, 34.

${ }^{30}$ HUB 6, no. 582; '...till Helliglannd, Finndtmarckit, Isslannd och annden (stedtz) wdij wort skattelannd...'; Baasch 1889, 6ff.

${ }^{31}$ See the paper of Geir Atle Ersland this volume; Nedkvitne 2014, 372.

${ }^{32}$ HUB 6, no. 1004; 7, no. 27.

${ }^{33}$ Nedkvitne 2014, 497-511, esp. Table VI, 2, 506, 550.

${ }^{34}$ It is conceivable that the Bergen staple was not affected by the Iceland trade or that any deleterious effects diminished over time (see Baasch 1889, 4), since according to Knut Helle virtually no Icelandic fish was brought to Bergen since the beginning of the fifteenth century and consequently the Icelandic fishermen were not caught up in the Hanseatic credit system in Bergen (Helle 1982, 790); this in contrast to the fishermen of Shetland, Orkney and the Faroes who did bring their fish to Bergen: Schreiner 1941, 43-49. Note, however, that Nedkvitne 2014, does designate Icelanders as debtors of Lübeck Bergen traders (ibid., 413; citing Bruns 1900, 19, 61 ) and points out a special customs toll on the Iceland trade imposed by the king of Norway in Bergen from the 1360s onwards, called 'sæckiagiald' (ibid., 311).

${ }^{35}$ Baasch 1889, 14f.; Bei der Wieden 1994, 11ff.; Friedland 1995a, passim; Friedland 1995b, $194 \mathrm{f}$.

36 Baasch 1889, 12.

37 Wubs-Mrozewicz 2008, 82-91, 104-113; Nedkvitne 2014, 461-466.

${ }^{38}$ On the following see Nedkvitne 2014, 461-466.

${ }^{39}$ For the prohibition of the Diet of 1412, that no Hanseatic merchant sell goods to non-Hansards for resale see $H U B$ 5, no. 1015; HR I, 6, no. 70, $\$ 17$.

${ }^{40}$ Nedkvitne 2014, 152-154.

${ }^{41}$ See n. 37 above.

${ }^{42}$ For the scholarship on these groups see the summary of Burkhardt 2009, 81-85.

${ }^{43}$ Ibid., 67-71.

${ }^{44}$ Danielsen 1995, 112-115; Olesen 1993, 111-113.

45 Wubs-Mrozewicz 2013, 453-472.
${ }^{46}$ HR II, 1, no. 393, art. 12, p. 316-318, here p. 318; on 'Vynlande' see note. 15 above; Nedkvitne 2014, 188, is of the opinion that the Bruges Kontor made 'an open request for clarification of what Hansa policy was' in the interest of those merchants wishing to trade with the 'schatlande'. However, this characterization is false: it was a petition to enforce the decree: 'begherd de copman, dat de ordinancie gheholden werde'. In my view, the aldermen of the Kontor were fearful that the Bruges staple would be endangered if the regulations of the Bergen staple on the North Atlantic trade were so openly flouted.

${ }^{47} H R$ II, 1, no. 394, \$10, p. 318f., here p. 319; NGL II.rk. I, no. 385 .

${ }^{48}$ See the papers by Adolf Hofmeister and Klaus-Joachim Lorenzen-Schmidt in this volume.

${ }^{49}$ HR II, 6, p. 69.

${ }^{50} H R$ III, 1, no. 351, pp. 293ff.; see also no. 350, p. 253; DN VI, no. 589 .

${ }^{51}$ This procedure is described minutely by Schipmann 2004, 67-73, based on sixteenth-century sources.

${ }^{52}$ HR III, 1 , no. $365, \$ 42$, pp. 303f., here p. 307.

${ }^{53}$ HR III, 1, 392, n. 1.

${ }^{54}$ DN VI, no. 609; quoted from $H R$ III, 2, p. 381ff., n. 2.

${ }^{55}$ HR III, 1, no. 410, pp. 416ff.

${ }^{56}$ HR III, 1, no. 501, pp. 395-411, \$\$93-97, p. 407; letter to Danzig: HR III, 1, no. 510, p. $416 f$.

${ }^{57}$ HR III, 2, no. 160, \$149, p. 152.

58 This speaks for the view that Iceland was in the process of breaking free from the Bergen staple or had done so already (see n. 34 above).

${ }^{59}$ HUB 11, no. 133, \$54, p. $108 \mathrm{ff}$.

${ }^{60}$ Ibid. $\$ 128$, p. 119.

${ }^{61}$ HR III, 2, no. 270, pp. 309-312 (1489, March 12); a month before, on 11 February 1489, Lübeck had replied to Wismar that it would not permit a ship loaded for Iceland to depart, but that nonetheless Hamburg merchants were sailing to Iceland, requesting Wismar to interdict the Iceland trade until the next meeting of the Wendish towns, at which the said resolution was passed: HR III, 2, no. 269, p. 308f.

${ }^{62}$ HUB 11, no. 275, p. 200 (25 February 1489).

${ }^{63}$ HR III, 3, no. 353, \$87, p. 278.

${ }^{64}$ HR III, 9, no. 131, \$162, p. 226.

${ }^{65} H R$ III, 4, no. 68, p. 69 ff.

${ }^{66}$ HR III, 9, no. 698, \$2, pp. 889ff.

${ }^{67}$ HR III, 6, no. 188, p. 118-149, \$139, p. 147; again in 1517 the Diet resolved that Hanseatic merchants should deal peaceably with the English in Iceland insofar as possible ('so verne mogelick'): $H R$ III, 7, no. 39, pp. 22-65, \$165, p. 42.

${ }^{68}$ Report by Johann Reinken, the secretary of the Hamburg town council, on the negotiations in Copenhagen: $H R$ III, 6, no. 505, pp. 448-456, $\$ \$ 37,40,41$, pp. 454-456.

${ }^{69}$ HR III, 6, no. 515, p. 475 (calendered); DN VI, no. 657.

${ }^{70}$ HR III, 9, no. 737, p. 920 et seq.; the 'White paper concerning the decline of the Bergen Kontor' [1514] is published by: Bruns 1900, 211-214. - On the 'stockfish mills' see most recently Wubs-Mrozewicz 2009, 197ff.

${ }^{71}$ HR III, 6, no. 673, p. 648 (calendered). Original AHL, 
Urkunden, Norwegica no. 87; published: DN VI, no. 659.

${ }^{72}$ HR III, 7, no. 39, pp. 22-65, \$\$190, 191, pp. 45ff.

${ }^{73}$ HR III, 7, no. 51, pp. 98ff.; '...thom ende sick grote swichtinge unde vorkrenkinge is to vruchten veles gudes handels uth sulker egentliker privater segalitie (!) wert erhevende, denne deme gemeinen kopmanne enne dem guden kuntor'.

${ }^{74}$ HR III, 7, no. 108 , pp. 142-187, $\$ 77$, p. 152

75 Ibid., \$161, p. 162 and no. 110, pp. 187-192, \$13, pp. 190ff.; for the situation in England see Jörn 2000, s.v. Bergen and Island.

${ }^{76}$ HR III, 7, no. 151, p. 343, \$2; ibid. no. 197, pp. 386-393, $\$ 41-43$, p. 392.

${ }_{77}$ See n. 36 above.

${ }^{78}$ See n. 51 above.

${ }^{79}$ HR III, 7, no. 197, pp. 386-393, \$44, p. 392.

${ }^{80}$ HR III, 7, no. 246, pp. 440-451, $\mathbb{S} 94-99$, pp. 449ff.

${ }^{81}$ HR III, 7, no. 340 , pp. $613-615$, $\$ 20$, p. 615 ; no. 455 , pp. 857-864, \$\$14, 15, pp. 860f.; no. 456, pp. 864-876, \$15, p. 870 .

${ }^{82}$ HR III, 7, no. 413, pp. 698-747, $\$ \$ 143-146$, p. 719, $\$ 325$, p. 744 .

${ }^{83}$ HR III, 8, no. 193 , pp. $220-222$, p. 221 ; no. 320 , pp. $338-$ 341 , p. 340 ; no. 321 , pp. 341 ff., $\$ 5$, p. 342 ; no. 674 , pp. 574-580, \$64, p. 578.

${ }^{84}$ HR III, 8, no. 820, $\$ 92$, p. 849; 'uthgenamen van der Islandesschen reyse; de sulve scholde stan blyven umbe der Hamburger wyllen, de nu groth gehor hedden by k. w.'; for the draft of the privilege see HR III, 8, no. 851, p. 880 (calendered), published DN XVI, no. 426, pp. 508510; Original in AHL, ASA Externa, Bergenfahrer 1289; the conditional confirmation of the privileges by King Frederick I (who was as yet uncrowned and therefore unable to produce a final confirmation): $H R$ III, 8, no. 826, p. 856 ; AHL, ASA Externa, Bergenfahrer 1290 (copy).

${ }^{85}$ HR III, 9, no. 131, \$168, p. 227; see also Friedland 1995a, 162.

${ }^{86}$ HR III, 9, no. 131, \$\$161-163, p. 226.

${ }^{87}$ 1533: HR IV, 1, no. 176, pp. 158ff. (on the trade with the North Atlantic islands); 1534 in regard to negotiations on compensation between Hamburg and Bremen: HR IV, 1 , no. 228 , pp. 179-189, $\$ 16$, p. 182 (on the Iceland trade).

${ }^{88}$ HR IV, 2, no. 86, pp. 54-167, \$600, p. 166.

${ }^{89}$ HR IV, 1, no. 173 , pp. 136-156, \$127, p. 154 et seq.; on this see also DN IX, 683; DN VIII, 746; the appointment of the two Hamburg merchants points to a conflict between the Danish king and the Norwegian Council of the Realm, which was demanding the subordination of the Faroes to Bergenhus, but was abolished in 1536; see above, n. 44.

${ }^{90}$ See Wubs-Mrozewicz 2009, 201-206.

${ }^{91}$ Archiv der Bergenfahrerkompanie zu Lübeck 2002.

${ }_{92}$ Wubs-Mrocewicz 2008, 149. See n. 57 above.

93 The meeting of the Wendish towns in Lübeck, April 1519: HR III, 7, no. 197, \$42, 44.

${ }_{94}$ Wubs-Mrocewicz 2008, 184 and note 97. See n. 35 above.

${ }^{95}$ Pitz 2001, 365-417; Schipmann 2004, 15-102.

${ }^{96}$ HR I, 6, no. 262, $\$ \$$ 89-92, pp. 216f.; NGL II, rk. I, no. 377.
${ }^{97}$ See n. 27 above.

98 The same thing occurred in 1494 and 1525 when the trade to Orkney, Shetland and the Faroes was prohibited yet again. See n. 62 and 63 above.

${ }^{99}$ HR I, 6, no. 262, \$90; NGL 2, rk. I, no. 377.

${ }^{100}$ I am not aware of a single case in which a Hanseatic merchant was subjected to the penalty forseen for engaging in illegal trade with Shetland, Orkney and the Faroes.

${ }^{101}$ According to Wubs-Mrozewicz 2008, 71, the privilege of 1490 redounded to the disadvantage of the Hollanders, who lost rights they had previously possessed.

${ }^{102}$ Helmrath 2013, 36.

${ }^{103}$ Seier 2012, 93-126.

\section{References}

Printed sources (see also list of abbreviations)

Norske middelalderdokumenter, eds Bagge, S. Holstad Smedsdal and K. Helle. Bergen: Universitetsforlaget, 1973.

\section{Secondary literature}

Archiv der Bergenfahrerkompanie zu Lübeck und des Hansischen Kontors zu Bergen in Norwegen von (1278) bzw. 1314 bis 1853. Archiv der Hansestadt Lübeck, Findbücher 9, ed. G. Asmussen, U. Simon, O. Wiehmann. Lübeck: Schmidt-Römhild, 2002.

Baasch, E. 1889. Die Islandfahrt der Deutschen, namentlich der Hamburger vom 15. bis 17. Jahrhundert. Hamburg: Herold'sche Buchhandlung.

Bei der Wieden, H. 1994. Lübeckische Islandfahrt vom 15. bis 17. Jahrhundert. Zeitschrift des Vereins für Lübeckische Geschichte und Altertumskunde 74, 9-29.

Bruns, F. 1900. Die Lübecker Bergenfahrer und ihre Chronistik. Berlin: Pass und Garleb.

Burkhardt, M. 2009. Der hansische Bergenhandel im Spätmittelalter. Handel - Kaufleute - Netzwerke. Cologne: Böhlau.

Childs, W. 1995. England's Icelandic trade in the fifteenth century: the role of the port of Hull, in P. Holm, O. Janzen and J. Thór (eds), Northern Seas Yearbook 1995, Association for the History of the Northern Seas, 11-31. Esbjerg: Fiskeri- og Søfartsmuseet.

Danielsen, R. 1995, Norway: A History from the Vikings to our own Times. Oslo: Scandinavian University Press.

Deeters, J. 2005. Hansische Rezesse. Eine quellenkundliche Untersuchung anhand der Überlieferung im Historischen Archiv der Stadt Köln, in R. HammelKiesow and M. Hundt (eds), Das Gedächtnis der Stadt Lübeck. Festschrift für Antjekathrin Graßmann zum 65. Geburtstag, 427-446. Lübeck: Schmidt-Römhild.

Dollinger, P. 2012 (newly edited by Volker Henn and Nils Jörn). Die Hanse. 6th revised edition. Stuttgart: Alfred Kröner Verlag.

Forstreuter, K. 1967. Zu den Anfängen der hansischen Islandfahrt. Hansische Geschichtsblätter 85, 111-119. 
Friedland, K. 1995a. Lübeck und Island. Die ältere Islandschifffahrt Lübecks, in K. Friedland A. Grassmann, R. Hammel-Kiesow and H.-D. Loose (eds), Mensch und Seefahrt zur Hansezeit, 158-164. Cologne: Böhlau.

Friedland, K. 1995b. Der hansische Shetlandhandel, in K. Friedland A. Grassmann, R. Hammel-Kiesow and H.-D. Loose (eds), Mensch und Seefahrt zur Hansezeit, 190-205. Cologne: Böhlau.

Gelsinger, B. E. 1981. Iceland Enterprise: Commerce and Economy in the Middle Ages. Columbia, SC: University of South Carolina Press.

Helle K. 1982. Bergen Bys Historie vol. I. Kongssete og kjøpstad. Fra opphavet til 1536. Bergen: Universitetsforlag.

Helmrath, J. 2013. Deutsche Reichstagsakten unter Kaiser Friedrich III. Fünfte Abteilung, Zweiter Teil. Reichsversammlung zu Frankfurt 1454. Munich: Oldenbourg.

Hofmeister, A. E. 2000. Hansische Kaufleute auf Island im 15. und 16. Jahrhundert, in Kirche - Kaufmann Kabeljau, 33-46. Bremen: Staatsarchiv Bremen.

Huang, A. and Kypta, U. 2011. Ein neues Haus auf altem Fundament. Neue Trends in der Hanseforschung und die Nutzbarkeit der Rezesseditionen. Hansische Geschichtsblätter 129, 213-230.

Jenks, S. 1992. A capital without a state: Lübeck caput tocius hanze (to 1474). Historical Research 65, 134-149.

Jörn, N. 2000. With Money and Bloode. Der Londoner Stalhof im Spannungsfeld der englisch-hansischen Beziehungen im 15. und 16. Jahrhundert. Cologne: Böhlau.

Karlsson, G. 2000. Iceland's 1100 Years: The History of a Marginal Society. London: Hurst.

Nedkvitne, A. 2014. The German Hansa and Bergen 1100-1600. Cologne: Böhlau.

Olesen, J. 1993. Council of the Realm (Riksråsd), in P. Pulsiano (ed.), Medieval Scandinavia: An Encyclopedia, 111-113. New York: Garland.
Pitz, E. 2001. Bürgereinung und Städteeinung. Studien zur Verfassungsgeschichte der Hansestädte und der deutschen Hanse. Cologne: Böhlau.

Ræstad, A. 1912. Konges Strömme. Kristiana: Cammermeyer.

Schipmann, J. L. 2004. Politische Kommunikation in der Hanse (1550-1621). Hansetage und westfälische Städte. Cologne: Böhlau.

Schreiner, J. 1941. Hanseatene og Norge i det 16. Arhundre. Oslo: Dybwad.

Seier, M. 2012. Die Hanse auf dem Weg zum Städtebund: Hansische Reorganisationsbestrebungen an der Wende vom 15. zum 16. Jahrhundert. Hansische Geschichtsblätter 130, 93-126.

Sigurðsson, J. V. 2010. The Norse Community, in S. Imsen (ed.), The Norwegian Domination and the Norse World c. 1100-c. 1400, 49-73. Trondheim: Tapir Academic Press.

Starkey, D. J., Reid C. and Ashcroft, N. (eds) 2000. England's Sea Fisheries: The Commercial Sea Fisheries of England and Wales since 1300. London: Chatham Publishing.

Taranger, A. 1904. Udsigt over den norske Rets Historie II. Christiania: Cammermeyer.

Wærdahl, R. B. 2011. The Incorporation and Integration of the King's Tributary Lands into the Norwegian Realm, c. 1195-1397. Leiden: Brill.

Wubs-Mrozewicz, J. 2008. Traders, Ties and Tensions. The Interaction of Lübeckers, Overijsslers and Hollanders in Late Medieval Bergen. Hilversum: Verloren Publishers.

Wubs-Mrozewicz, J. 2009. Fish, stock and barrel. Changes in the stockfish trade in northern Europe, c. 1360-1560, in L. Sicking and D. Abreu-Ferreira (eds), Beyond the Catch. Fisheries of the North Atlantic, the North Sea and the Baltic, 900-1850, 187-208. Leiden: Brill.

Wubs-Mrozewicz, J. 2013. The close 'other'. Hollanders in medieval Hanseatic sources and in historiography. German History 3/4, 453-472. 